\title{
Pengaruh Model Pembelajaran Terpadu Tipe Shared Berbantu Media Pop- Up Book Terhadap Hasil Belajar
}

\author{
${ }^{1}$ Shofiatun Nikmah, ${ }^{2}$ Harto Nuroso, ${ }^{3}$ Fine Reffiane \\ 1,2,3 Jurusan Pendidikan Guru Sekolah Dasar, Universitas PGRI Semarang \\ e-mail: ${ }^{1}$ nikmah.sofy19@gmail.com ${ }^{2}$ hartonuroso@upgris.ac.id ${ }^{3}$ finereffiane@upgris.ac.id
}

\begin{abstract}
Abstrak
Penelitian ini dilakukan untuk meningkatkan hasil belajar siswa kelas IV SDN Sukorejo 02 Semarang melalui model pembelajaran terpadu tipe shared berbantu media pop-up book. Sebelumnya hasil belajar siswa dalam penilaian tengah semester masih rendah dikarenakan dalam kegiatan belajar mengajar guru perlu melakukan inovasi dalam penggunaan model pembelajaran supaya siswa tidak mudah bosan. Diharapkan siswa bersemangat dalam mengikuti pembelajaran serta dapat aktif dalam menjawab pertanyaan dari guru mengenai materi yang dipelajari. Subyek penelitian ini adalah siswa kelas IV SDN Sukorejo 01 Semarang sebagai kelas kontrol dan SDN Sukorejo 02 Semarang sebagai kelas eksperimen yang memiliki jumlah keseluruhan 60 siswa. Penelitian ini adalah penelitian eksperimen kuantitatif menggunakan Quasi Experimental Design dengan jenis None quivalent Control Grup Design. Desain ini terdapat dua kelompok yang masing-masing dipilih secara rondom (R). Kelompok pertama diberi perlakuan $(X)$ dan yang lain tidak diberi perlakuan. Kelompok yang diberi perlakuan disebut kelompok eksperimen dan kelompok yang tidak diberi perlakuan disebut kelompok kontrol.
\end{abstract}

Kata Kunci: Shared model, meningkatkan hasil belajar siswa

\begin{abstract}
This research was conducted to improve the learning outcomes of fourth grade students of SDN Sukorejo 02 Semarang through an integrated type of shared learning model supported by pop-up book media. Previously the student learning outcomes in midterm assessments were still low because in teaching and learning activities teachers needed to innovate in the use of learning models so students were not easily bored. It is expected that students are enthusiastic in participating in learning and can be active in answering questions from teachers regarding the material being studied. The subjects of this study were fourth grade students of SDN Sukorejo 01 Semarang as a control class and SDN Sukorejo 02 Semarang as an experimental class which had a total number of 60 students. This study was a quantitative experimental study using Quasi Experimental Design with None quivalent Control Design Group. two groups each selected rondom $(R)$. The first group was given treatment $(X)$ and the other was not treated. The group given the action is called the experimental group and the group that is not treated is called the control group.
\end{abstract}

Keywords: Shared models, improve student learning outcomes 


\section{Pendahuluan}

Setiap warga negara Indonesia wajib mendapatkan pendidikan yang layak. Melalui pendidikan, manusia melakukan kegiatan belajar yakni memperoleh pengetahuan dan pengalaman yang didapatkan saat proses pembelajaran dilaksanakan. Belajar dialami sebagai suatu proses. Siswa mengalami proses mental dalam menghadapi bahan belajar. Teori Gestalt (dalam Wahyuni, 2017:85) menyatakan "belajar merupakan suatu proses perkembangan". Artinya bahwa secara kodrati jiwa raga anak mengalami perkembangan. Dunia pendidikan selalu mendapatkan sorotan yang tajam berkaitan dengan tuntutan untuk menghasilkan sumber daya manusia yang berkualitas dan mampu menghadapi perkembangan ilmu pengetahuan. Proses pembelajaran harus dilaksanakan dengan baik agar dapat membantu siswa menyerap materi pembelajaran.

Pada zaman modern ini dalam dunia pendidikan perlu diadakannya suatu inovasi yang pastinya menguntungkan pihak pengajar dan pihak pebelajar. Inovasi tersebut dilakukan agar pembelajaran yang dilaksanakan tidak konsisten itu-itu saja atau dengan perangkat belajar yang itu-itu saja. Guru menyadari bahwa kurangnya suatu inovasi dalam pembelajaran akan mempengaruhi hasil belajar peserta didik itu sendiri. Pada saat ini siswa lebih menyukai pembelajaran yang dikaitkan langsung dengan sebuah alat bantu pembelajaran yang lain dari pada yang lain seperti media pembelajaran. Kegiatan pembelajaran yang baik tidak lepas dari peran media dalam proses pembelajaran. Peran media sangat penting sebagai alat bantu siswa belajar. Dalam pemilihannya pun media harus sesuai dengan karakteristik siswa karena dengan begitu siswa dapat berperan aktif dalam proses belajar.

Pendidikan adalah kebutuhan yang mendasar pada masa sekarang ini sebagai sarana untuk pembentukan warga negara yang cerdas, cakap, kreatif, bertanggung jawab dan berkualitas. Menurut Fitriani (2018) pendidikan adalah salah satu aspek penting yang akan menentukan kualitas hidup seseorang maupun suatu bangsa, oleh sebab itu masalah pendidikan di Indonesia menjadi perhatian penting bagi bangsa Indonesia saat ini. Seiring dengan berkembangnya zaman maka kualitas pembelajaran di Indonesia harus selalu ditingkatkan. Fakta yang diperoleh tidak sedikit sekolah yang kurang memperhatikan kualitas dari pembelajaran sehingga hasil belajar yang dihasilkan kurang maksimal. Seperti yang terkandung pada fungsi dan tujuan pendidikan nasional menurut Undang-Undang Nomor 20 tahun 2003 tentang Sistem Pendidikan Nasional bab 3 pasal 2. Menurut Murfiah (2017) Pendidikan sebagai proses belajar merupakan proses pendewasaan yang dilakukan oleh seorang guru dan peserta didik. Guru sebagai salah satu sumber ilmu menyampaikan materi yang bermakna bagi peserta didik. Sebagai pendidik guru pun harus tetap belajar, jika guru tidak meningkatkan ilmunya maka guru akan tertinggal dengan pesatnya ilmu pengetahuan dan teknologi. Belajar dalam arti yang luas harus dilakukan oleh guru, apalagi peserta didik. Pendidikan nasional berfungsi mengembangkan kemampuan dan membentuk-watak serta peradaban bangsa yang bermartabat dalam rangka mencerdaskan kehidupan bangsa, bertujuan untuk berkembangnya potensi peserta didik agar menjadi Manusia yang beriman dan bertaqwa kepada Tuhan Yang Maha Esa, berakhlak mulia, sehat, berilmu, cakap, kreatif, mandiri, dan menjadi warga negara yang demokratis serta bertanggung jawab.

Perubahan KTSP menjadi Kurikulum 2013 memerlukan penyesuaian dalam kegiatan pembelajaran, media pembelajaran serta buku guru dan siswa. Menurut ibu Puji Priyani S.Pd, selaku guru kelas IV SDN Sukorejo 02 Semarang yaitu guru harus mampu menggunakan waktu pembelajaran sebaik mungkin supaya semua materi dapat tersampaikan kepada siswa, sedangkan dalam satu hari guru harus menyelesaikan 1 pembelajaran yang mencangkup 2 sampai 3 mata pelajaran. Mendesain pembelajaran berbasis multimedia perlu diterapkan untuk menunjang pembelajaran sementara alat pembelajaran yang digunakan belum memadai, sehingga dalam membantu kegiatan belajar mengajar guru memilih menggunkan benda konkrit yang ada di dalam kelas serta mengajak siswa mengingat peristiwa sehari-hari yang dialami oleh siswa kemudian guru membantu siswa menghbungkan peristiwa yang terjadi dengan materi yang akan dipelajarai. Meski perubahan KTSP menjadi Kurikulum 2013 memerlukan penyesuaian namun beliau tetap optimis untuk menuju perubahan yang lebih baik serta memiliki keinginan menjadikan siswa mandiri dan memiliki wawasan yang luas mengenai ilmu pendidikan.

Salah satu permasalahan dalam pendidikan di sekolah dasar adalah rendahnya hasil belajar siswa, salah satunya pada pembelajaran terpadu. Pembelajaran terpadu diharapkan siswa mampu berkembang dengan bekal pengetahuan yang diperoleh ketika disekolah. Salah 
satu faktor penyebab kesulitan dalam pembelajaran terpadu ialah kurangnya pemahaman siswa serta kesulitan siswa dalam menerima materi yang, karena Pembelajaran terpadu dianggap telah dipelajari. Pembelajaran juga masih berpusat pada guru, apabila dilihat dari metode yang digunakan pada kelas IV SDN Sukorejo 02 Semarang guru sudah menggunakan model pembelajaran hanya saja perlu dilakukan inovasi model pembelajaran berbantu media supaya siswa antusias dalam mengikuti pembelajaran.

Menurut Slameto (2010:2) belajar adalah suatu proses usaha yang dilakukan seseorang untuk memperoleh suatu perubahan tingkah laku yang baru secara keseluruhan, sebagai hasil pengalamanya sendiri dalam interaksi dengan lingkungan. Secara psikologi, belajar merupakan suatu proses perubahan yaitu perubahan tingkah laku sebagai hasil interaksi dengan lingkunganya dalam memenuhi kehidupan hidupnya.Menurut Aunurahman (2012:35) belajar adalah suatu proses yang dilakukan individu untuk memperoleh suatu perubahan tingkah laku yang baru secara keseluruhan, sebagai hasil pengalaman individu itu sendiri di dalam interaksi dengan lingkunganya.

Rusman (2017:129) mengemukakan bahwa hasil belajar adalah sejumlah pengalaman yang diperoleh siswa mencangkup ranah kognitif, efektif, dan psikomotor.Belajar tidak hanya penguasaan konsep teori mata pelajaran saja, tetapi juga kebiasaan, persepsi, kesenangan, minat-bakat, penyesuaian social, jenis-jenis ketrampilan, cita-cita, keinginan, dan harapan". Menurut Hamalik dalam Rusman (2017: 130) menyatakan bahwa hasil belajar itu dapat dilihat dari terjadinya perubahan dari persepsi dan perilaku, termasuk juga perbaikan perilaku.

Menurut Munandi (2013: 24) ada 2 faktor yang dapat mempengaruhi hasil belajar siswa diantaranya 1. Faktor Internal yang meliputi (a) Faktor Fisiologisyaitu secara umum kondisi fisiologis, seperti kesehatan yang prima, tidak dalam keadaan lelah dan capek, tidak dalam keadaan cacat jasmani, dan sebagainya, semuanya akan membantu dalam proses dan hasil belajar. (b) Faktor Psikologis, beberapa faktor psikologis yang dapat diuraikan di antaranya meliputi intelegensi, perhatian, minat dan bakat, motif dan motivasi, dan kognitif dan daya nalar. Sedangkan faktor Ekstrnal (a) Faktor Lingkungan, kondisi lingkungan juga mempengaruhi proses dan hasil belajar. Lingkungan ini dapat berupa lingkungan fisik atau alam dan dapat pula berupa lingkungan sosial.Lingkungan alam misalnya keadaan suhu, kelembapan, kepengapan udara, dan sebagainya. (b) Faktor Instrumental, selama proses belajar mengajar berlangsung, terjadilah interaksi antara guru dan siswa, namun interaksi ini bercirikan khusus, karena siswa menghadapi tugas belajar dan guru harus mendampingi siswa dalam belajarnya.

Hasil penilaian tengah semester kelas IV SDN Sukorejo 02 Semarang pada semester genap tahun ajaran 2018/2019 pada pembelajaran terpadu menunjukan bahwa 10 siswa mendapatkan nilai di atas 75 dan 20 siswa mendapatkan nilai di bawah 75 . Hasil penilaian tersebut menunnjukan bahwa masih banyak siswa yang belum mampu menguasai materi yang telah dipelajari, maka perlu dilakukan perubahan dalam meningkatkan hasil belajar siswa dalam pembelajaran terpadu yaitu dengan penggunaan model pembelajaran yang cocok untuk membantu guru dalam menyampaiakn materi kepada siswa berbantu media pembelajaran yang menarik supaya mampu menarik perhatian siswa dalam mengikuti kegiatan pembelajaran di dalam kelas.

Pembelajaran tanpa model tidak akan mencapai tujuan yang di inginkan, untuk itu model merupakan upaya untuk mengimplementasikan rencana dalam kegiatan nyata agar tujuan yang telah di susun tercapai secara optimal. Model pembelajaran terpadu yang berkembang didasarkan oleh perkembangan pendidikan, sehingga tidak keliru dalam pemilihan model. Menurut Suryaningsih (2016) pembelajaran terpadu merupakan suatu aplikasi salah satu strategi pembelajaran berdasarkan pendekatan kurikulum terpadu yang bertujuan untuk menciptakan atau membuat proses pembelajaran secara relevan dan bermakna bagi anak. Terkait dengan pembelajaran terpadu, banyak kecenderungan yang tumbuh dan berkembang di saat ini. Sebagai inovasi model pembelajaran terpadu sesuai dengan tantangan masa sekarang maupun masa yang akan datang. Salah satunya adalah model tipe shared.

Model tipe shared (bagian) menurut Fogarty dalam Yusuf (2016) merupakan model pembelajaran dengan menggabungkan atau memadukan antara dua mata pelajaran yang saling melengkapi dan didalam perencanaan atau pengajaranya menciptakan satu fokus pada konsep, ketrampilan, serta sikap yang saling berhubungan satu sma lain dipayungi dalam satu tema.Setiap model dalam pembelajaran pasti memiliki kelebihan dan kekurangan, seperti model tipe shared yang akan saya gunakan dalam melaksanakan penelitian, menurut Fogarty dalam Yusuf (2016) model pembelajaran tipe shared (bagian) kelebihanya yaitu mampu mentransfer konsep secara mendalam sedang Kekuranganya yaitu terletak pada penyusunan rencana 
model pembelajaran. Diperlukan kerjasama guru antar mata pelajaran yang berbeda sehingga diperlukan waktu yang ekstra untuk mendiskusikanya.

Selain model media juga berpengaruh untuk menunjang keberhasilan guru dalam menyampaikan materi. Menurut Rusman (2017:214) media adalah pengantar pesan dari pengirim ke penerima pesan, dengan demikian media merupakan wahana penyalur informasi belajar atau penyalur pesan. mendefinisikan "media sebagai segala bentuk dan saluran yang digunakan seseorang untuk menyalurkan pesan/informasi". Pop-up book adalah sebuah buku cerita bergambar dengan gambar yang lucu atau bentuknya menarik karena dapat bergerak ketika halamanya dibuka. Pengertian lain menurut Montanaro dalam Dula (2017) pop-up book merupakan sebuah buku yang memiliki bagian yang dapat bergerak atau memiliki unsure 3 dimensi.

Lebih lagi Mukhadis (2014) menyatakan bahwa ada peningkatan hasil belajar setelah menggunakan model pembelajaran terpadu tipe shared yaitu (1) meningkatkan pemahaman dan penghayatan mahasiswa terhadap isi pembelajaran pada tingkat bermakna (2) meningkatkan ketrampilan mengidentifikasi, mencari, mengemas dan melaporkan hasil informasi yang relevan sebagai orientasi pembelajaran (3) Meningkatkan pembelajaran aktif, kreatif, inovatif, menyenangkan dan menantang (4) Mengembangkan sikap positif mahasiswa terhadap prakarsa dan tindak belajar, sikap mandiri, kreatif dan produktif.

Salah satu komponen pembelajaran adalah media pembelajaran. Media pembelajaran adalah sarana untuk memberikan perangsang bagi anak supaya proses belajar mengajar terjadi (Sumanto \& Seken,2012:5). Rangsangan yang dimaksud ini adalah perhatian, minat, pikiran, dan perasaan siswa dalam kegiatan belajar untuk mencapai tujuan pembelajaran tertentu. Sedangkan menurut Gagne' dan Briggs (dalam Arsyad, 2014:4) "media pembelajaran meliputi alat yang secara fisik digunakan untuk menyampaikan isi materi pengajaran, yang terdiri dari buku, tape-recorder, kaset, video camera, video recorder, film, slide (gambar bingkai), foto, gambar, grafik, televisi dan komputer". Dengan demikian dapat disimpulkan bahwa media pembelajaran merupakan segala sesuatu yang digunakan untuk menyampaikan isi materi pembelajaran guna memudahkan siswa dalam memperoleh pengetahuan, keterampilan dan sikap sesuai tujuan pembelajaran.

Media memiliki kegunaan yang besar dalam proses pembelajaran yang berlangsung di kelas. Seperti yang diungkapkan Sadiman (2010:17), kegunaan media dalam pembelajaran antara lain bisa mengatasi keterbatasan ruang, waktu dan daya indera. Penggunaan media yang sesuai dengan situasi dan kondisi dalam kelas akan meminimalisir waktu yang dibutuhkan guru untuk menyampaikan isi pembelajaran. Kemp \& Dayton (1985) (dalam Arsyad, 2014:19) mengungkapkan bahwa media memenuhi tiga fungsi utama yakni memotivasi, menyajikan informasi dan memberi instruksi. Berdasarkan uraian tersebut, fungsi dari penggunaan media pembelajaran antara lain sebagai alat untuk menarik perhatian siswa, menyampaikan materi pembelajaran, serta membantu siswa untuk memahami materi yang dipelajari. Sejalan dengan Hamalik (2008) (dalam Wisnu Lazuardi Yusuf, 2018) yang mengungkapkan bahwa penggunaan media pembelajaran dapat mewujudkan situasi pembelajaran yang efektif, mempercepat proses pembelajaran, dan membantu siswa dalam upaya memahami materi yang disampaikan guru di dalam kelas.

Lebih detail, fungsi dari penggunaan media pembelajaran menurut Fathurrohman \& Sutikno (2009:67) antara lain; (1) Menarik perhatian siswa, (2) Membantu untuk mempercepat pemahaman dalam proses pembelajaran, (3) Memperjelas penyajian pesan agar tidak bersifat verbalistis (dalam bentuk kata-kata tertulis atau lisan), (4) Mengatasi keterbatasan ruang, (5) Pembelajaran lebih komunikatif dan produktif, (6) Pembelajaran lebih komunikatif dan produktif, (7) Waktu pembelajaran bisa dikondisikan, dan (8) Menghilangkan kebosanan siswa dalam belajar.

Menurut Diah (2018) yang melakukan penelitian di SD Mutiara mengatakan bahwa Media pembelajaran Pop-Up Book dinyatakan valid dan dapat digunakan untuk peserta didik dalam kegiatan belajar untuk meningkatkan hasil belajar IPA siswa kelas III A SD Mutiara Singaraja. Hal tersebut terbukti dengan hasil dari uji ahli dan uji coba siswa berikut, pada ahli isi mata pelajaran IPA endapatkan hasil $95,8 \%$ dengan kriteria sangat baik, penilaian pada ahli desain pembelajaran mendapatkan hasil $88 \%$ dengan kriteria baik, penilaian ahli media pembelajaran mendapatkan hasil $98,5 \%$ dengan kriteria sangat baik, pada uji coba perorangan mendapatkan hasil $92 \%$ dengan kriteria sangat baik, pada uji coba kelompok kecil mendapatkan hasil $91,66 \%$ dengan kriteria sangat baik, dan pada uji coba lapangan mendapatkan hasil $90,8 \%$ dengan kriteria sangat baik. 
Hal ini di dukung juga oleh Khoiriyah (2018) yang menyatakan bahwa tingkat kelayakan produk oleh ahli materi dan ahli media termasuk dalam kategori valid dan layak digunakan namun perlu direvisi. Dari hasil data keterterapan media menunjukkan hasil media pembelajaran Pop-Up Book valid dan layak diterapkan pada pembelajaran.

Berdasarkan hasil penelitian dan pengembangan yang telah dilakukan Safri (2017), maka disimpulkan bahwa media belajar pop-up book yang telah dikembangkan melalui model ADDIE, melalui tahapan analisis, desain, pengembangan, implementasi dan evaluasi dengan persentase kelayakan rata-rata dari 5 validator sebesar 92,67 . Hal ini menunjukan bahwa media belajar pop-up book materi minyak bumi sangat layak digunakan sebagai media pembelajaran.

Penelitian ini bertujuan untuk mengetahui pengaruh model pembelajaran terpadu tipe shared berbantu media pop-up book pada tema 8 materi Daerah Tempat Tinggalku. Berdasarkan permasalahan dan fakta-fakta dan teori diatas, penelitian berjudul pengaruh model pembelajaran terpadu tipe shared berbantu media pop-up book terhadap hasul belajar siswa kelas IV SDN Sukorejo 02 Semarang perlu dilakukan.

\section{Metode}

Desain penelitian yang digunakan dalam penelitian ini adalah desain Eksperimen ,Metode penelitian ini menggunakan Quasi Experimental Design dengan jenis Nonequivalent Control Grup Design.

Gambar desain sebagai berikut :

$$
\frac{0_{1} \times 0_{2}}{0_{3} \mathrm{X}_{4}}
$$

Gambar 1. Desain Penelitian

Desain ini hampir sama dengan pretest-posttest kontrol group design, hanya saja dalam desain ini terdapat dua kelompok yang tidak dipilih secara rondom Sugiyono (2015: 116). Kedua kelompok dalam penelitian ini yaitu kelompok eksperimen dan kelompok kontrol, Pengaruh perlakuan adalah (02-01)-(04-03).

Penelitian ini dilaksanakan di SDN Sukorejo 01 Semarang sebagai kelas kontrol dan SDN Sukorejo 02 Semarang sebagai kelas eksperimen pada semester genap tahun ajaran 2018/2019 dengan jumlah peserta didik yang terdapat pada masing-masing kelas adalah 30 siswa. Satu kelas tidak diberi perlakuan dan kelas lainya mendapat perlakuan menggunakan model pembelajaran terpadu tipe shared berbantu media pop-up book. Penelitian dilakukan pada tanggal 18 Maret samapai 21 Maret 2019 yaitu 2 hari pada kelas kontrol dan 2 hari pada kelas eksperimen pada tema 8 materi Daerah Tempat Tinggalku yang masing masing kelas mendapatkan 2 kali pembelajaran.

Instrumen yang digunakan dalam penelitian ini dirancang untuk mengetahui perbedaan hasil belajar siswa sebelum diberi perlakuan dan setelah diberi perlakuan menggunakan model pembelajaran terpadu tipe shared berbantu media pop-up book. Dalam penelitian ini menggunakan metode tes, tes digunakan untuk mendapatkan data hasil belajar siswa pada tema 8 materi Daerah Tempat Tinggalku. Data yang dimaksud adalah hasil belajar kognitif siswa kelas IV SDN Sukorejo 02 Semarang. Tes dilakukan sebelum proses belajar mengajar dilaksanakan (pretest) dan sesudah proses belajar mengajar(posttest). Hasil ini juga digunkan untuk mengetahui pengaruh model pembelajaran terpadu tipe shared berbantu media pop-up book.

Selanjutnya yang harus dikerjakan adalalah teknik analisis data yang terdiri dari Uji Normalitas yang dilakukan untuk mengetahui bahwa sampel berasal dari populasi berdistribusi normal. Dalam tahap berikutnya melakukan Uji Homogenitas untuk mengetahui apakah kelas tersebut homogen dengan kriteria Ha ditolak dan Ho diterima. Yang terakhir yaitu Uji Hipotesis yang digunakan untuk menjawab hipotesis penelitian dengan menggunakan rumus Uji T degan kriteria $t_{\text {hitung }}<t_{\text {tabel. }}$. 


\section{Hasil dan Pembahasan}

Berdasarkan penelitian yang telah dilakukan, maka dapat diperoleh beberapa data untuk mengetahui meningkatnya hasil belajar siswa kelas IV SDN Sukorejo 02 Semarang dari kegiatan pembelajaran.Berikut ini diuraikan hasil penelitian yang telah didapatkan.

Perhitungan skor prettest

Setelah melakukan tes awal (pretest) tidak terdapat perbedaan secara signifikan antara skor nilai pretest siswa kelas kontrol dan eksperimen sebelum diberikan pembelajaran yaitu pada kelas kontrol terdapat 4 siswa dinyatakan tuntas dan 26 ssiwa dinyatakan tidak tuntas dengan rata-rata 59,7. Sedangkan pada kelas eksperimen terdapat 3 siswa dinyatakan tuntas dan 27 siswa dinyatakan belum tuntas dengan rata-rata 66 .

Tabel 1. Nilai pretest kelas kontrol dan eksperimen

\begin{tabular}{lccccccc}
\hline No & Kelas & Rata-rata & $\begin{array}{c}\text { Nilai } \\
\text { tertinggi }\end{array}$ & $\begin{array}{c}\text { Nilai } \\
\text { terendah }\end{array}$ & Tuntas & $\begin{array}{c}\text { Tidak } \\
\text { tuntas }\end{array}$ & $\begin{array}{c}\text { Jumlah } \\
\text { siswa }\end{array}$ \\
\hline 1. & Kontrol & 59,7 & 90 & 33 & 4 & 26 & 30 \\
2. & Eksperimen & 66 & 76 & 53 & 3 & 27 & 30 \\
\hline
\end{tabular}

Perhitungan skor posttest

Setelah dilakukan pembelajaran menggunakan model dan berbantu media hasil belajar siswa meningkat secara signifikan yaitu pada kelas kontrol yang tidak beri perlakuan terdapat 23 siswa mendapatkan nilai di atas 75 yang dinyatakan tuntas dan 7 siswa mendapatkan nilai di bawah 75 dinyatakan belum tuntas dengan rata-rata 75,6. Sedangkan pada kelas eksperimen yang mendapatkan perlakuan menggunakan model tipe shared berbantu media pop-up book terdapat 26 siswa yang mendapatkan nilai di atas 75 dinyatakan tuntas dan 4 siwa mendapatkan nilai di bawah 75 dinyatakan belum tuntas dengan rata-rata 82,6 dengan jumlah keseluruhan 30 siswa.

Tabel 2. Nilai posttest kelas kontrol dan eksperimen

\begin{tabular}{lccccccc}
\hline Kelas & $\begin{array}{c}\text { Rata- } \\
\text { rata }\end{array}$ & $\begin{array}{c}\text { Nilai } \\
\text { tertinggi }\end{array}$ & $\begin{array}{c}\text { Nilai } \\
\text { terendah }\end{array}$ & Tuntas & $\begin{array}{c}\text { Tidak } \\
\text { tuntas }\end{array}$ & $\begin{array}{c}\text { Jumlah } \\
\text { siswa }\end{array}$ \\
\hline 1. & Kontrol & 75,6 & 90 & 60 & 23 & 26 & 30 \\
\hline 2. & Eksperimen & 82,6 & 96 & 73 & 26 & 27 & 30 \\
\hline
\end{tabular}

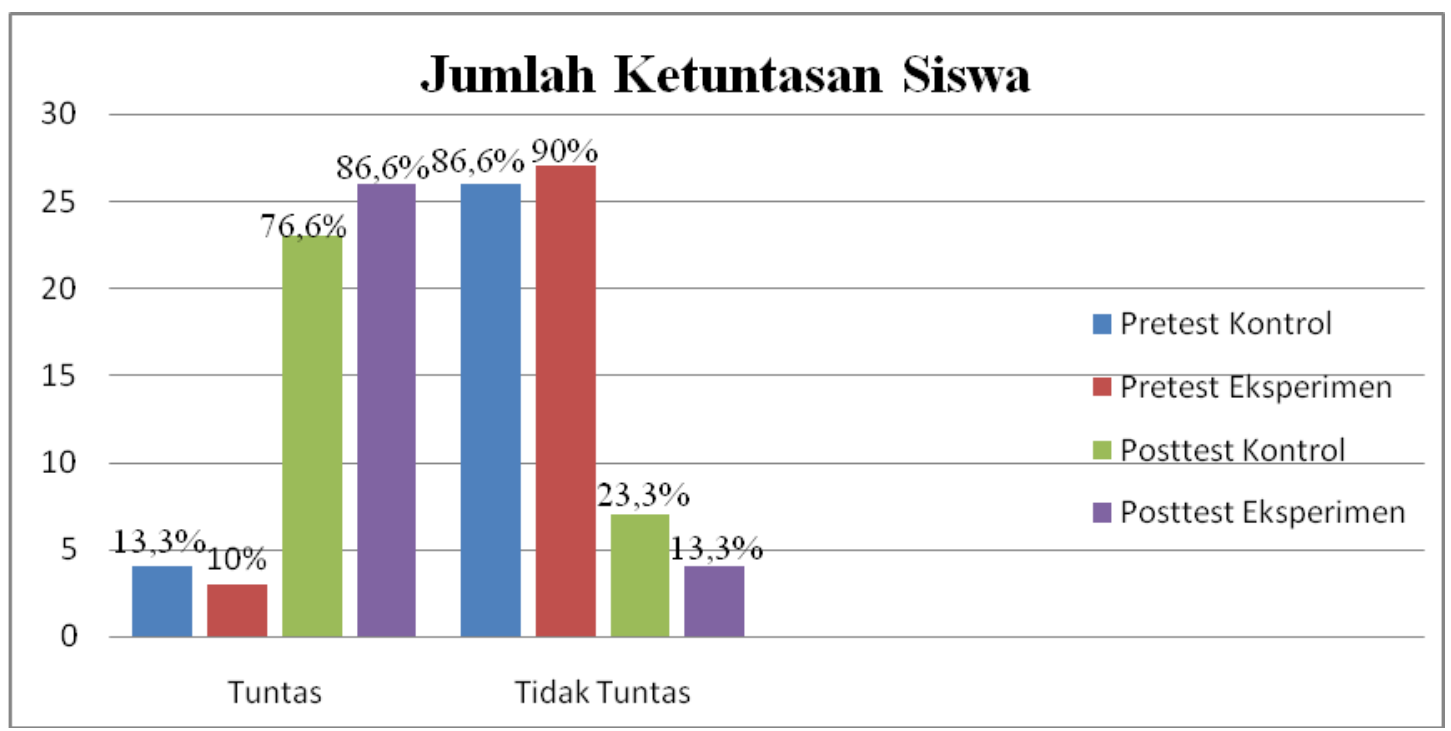

Gambar 2. Jumlah Ketuntasan Siswa

Berdasarkan hasil nilai pretest dan posttest pada kelas kontrorol dan eksperimen dapat dikatakan bahwa kelas tersebut berdistribusi normal dibuktikan dengan hasil normalitas kelas 
kontrol $L o=0,1281$ dan $L_{\text {tabel }}=0,161$ artinya $L_{0}<L_{\text {tabel }}$, maka Ho diterima kemudian untuk kelas eksperimen $L o=0,1517$ dan $L_{\text {tabel }}=0,161$ artinya $L_{0}<L_{\text {tabel }}$, maka Ho diterima. Selanjutnya kelas dapat dikatakan homogen jika $F_{\text {hitung }}<F_{\text {tabel }}$, pada hasil penelitian menunjukan bahwa $F_{\text {hitung }}=0,40$ dan $F_{\text {tabel }}=1,85$ maka Ha ditolak dan Ho diterima. Selanjutnya uji hipotesis, dalam penelitian ini menggunakan Uji T dengandk $=n 1+n 2-2=24+24-2=46$, a $5 \%$ didapatkan $t_{\text {tabel }}$ sebesar 1,711. Dari perhitungan di peroleht $t_{\text {hitung }}$ sebesar2,135. Berdasarkan kriteria $t_{\text {hitung }}>$ $t_{\text {tabel }}$ yaitu $2,135>1,711$ sehingga $\mathrm{H} 0$ ditolak dan Ha diterima. Artinya terdapat perbedaan nilai hasil belajar lebih baik antara sebelum (pretest) dan sesudah (posttest) yang menggunakan model tipe shared berbantu media pop-up book.

\section{Simpulan dan Saran}

Berdasarkan hasil penelitian yang dilakukan dapat disimpulkan bahwa model pembelajaran terpadu tipe shared berbantu media pop-up book berpengaruh terhadap hasil belajar siswa pada kelas IV SDN Sukorejo 02 Semarang. Hal ini dapat dilihat dari rata-rata nilai posttest lebih tinggi dari pada nilai pretest yaitu setelah diberi perlakuan menggunakan model pembelajarantipe shared, selain itu diperkuat dengan hasil perhitungan uji $t$ diperoleh $t_{\text {hitung }}$ untuk hasil belajar sebesar 2,135 dan $t_{\text {tabel }}$ sebesar 1,711 karena $t_{\text {hitung }}(2,135)>t_{\text {tabel }}(1,711)$ maka hal ini menunjukkan bahwa uji t hasil belajar signifikan. Kemudian saran dalam penelitian ini adalah: 1) Model pembelajaran terpadu tipe shared berbantu media pop-up book dapat meningkatkan hasil belajar peserta didik, oleh karena itu guru perlu menerapkan model pembelajaran tipe shared dengan baik, agar peserta didik lebih aktif, semangat dan antusias dalam mengikuti proses belajar mengajar didalam kelas, dan 2) Diharapkan penelitian ini dapat dijadikan salah satu referensi dalam melakukan penelitian oleh peneliti lain dengan materi yang berbeda.

Ucapan terimakasih penulis sampaikan kepada Drs. Harto Nuroso, M.Pd.,selaku dosen pembimbing satu yang selama ini sudah memberi arahan, bimbingan, dan motivasi kepada penulis sehingga dapat terselaisakanya artikel ini dengan baik. Fine Reffiane, S.Pd., M.Pd., sebagai dosen pembimbing 2 yang telah memberikan bimbingan, kritik dan saran selama penyusunan artikel ini. Sehingga artikel yang saya susun dapat terselesaikan dengan baik dan lancar.

\section{Daftar Pustaka}

Aunurrahman. 2012. Belajar dan Pembelajaran. Bandung: Alfabeta.

Dula Stefani, N, G. Pengembangan Media Pop-up Book Pada Materi Bentuk Permukaan Bumi Untuk siswa Kelas III SDN Mangunsari Semarang.Skripsi PGSD Universitas Negeri Semarang.Diakses tanggal 14 April 2019.

Elisa Diah. (2018). Pengembangan Media Pembelajaran Pop-Up Book pada Mata Pelajaran IPA Kelas II Sekolah Dasar. Jurnal Jurusan Teknologi Pendidikan.

Fitriani, Ayu, Eko Retno Mulyaningrum, Rivanna Cittraning Rachmawati. 2018. Komparasi Pembelajaran IPA Terpadu Tipe Connect dan Webbed Melalui LSLC terhadap Hasil Belajar Kognitif Siswa di SMP Negeri 11 Semarang. Florea : Jurnal Biologi dan Pembelajarannya, 5 (2) Hal. 91-99. Tersedia Pada : http://ejournal.unipma.ac.id/index.php/JF/article/view/3147/pdf.

Khoiriyah Evi. 2018. Pengembangan Media Pembelajaran Pop-Up Book pada Mata Pelajaran IPA Kelas III SDN 3 Junjung Kecamatan Sumbergempol Kabupaten Tulungagung Tahun Ajaran 2017/2018. Jurnal Bidang Pendidikan Dasar (JBPD), Vol.2 No.2 Juni 2018. http: ejournal.unikama.ac.id/index.php/JBPD

Munandi, Y. 2013. Media Pembelajaran: sebuah pendekatan baru .Jakarta : Ciputat Mega Mall

Mukhadis, A dan Ulfatin, N .2014 .Keefektifan dan Kemenarian Pembelajaran Terintegrasi Model Shared Berbasis Gallery Project.Journal IImu Pendidian.Vol.20, No.2 Desember 2014. 
Murfiah, Uum. 2017. Model Pembelajaran Terpadu di Sekolah Dasar. Jurnal Pesona Dasar Vol. 1 No. 5 Hal. 57-69. Tersedia Pada : http://www.jurnal.unsyiah.ac.id/PEAR/article/. (Diakses pada 7 Januari 2018).

Rusman. 2017. Belajar dan pembelajaran. Jakarta: Kencana

Safri Meilia. 2017. Pengembangan Media Belajar Pop-Up Book pada Materi Minyak Bumi. Jurnal Pendidikan Sains Indonesia, Vol. 05, No.01, hlm 107-113, 2017http://jurnal.unsyiah.ac.id/jpsi

Slameto. 2010. Belajar dan Faktor-Faktor yang Mempengaruhinya. Jakarta: PT Rineka Cipta.

Soegeng, A.Y . 2017. Filsafat Pendidikan. Yogyakarta: Magnum Pustaka Utama.

Sugiyono. 2015. Metode Penelitian Kuantitatif dan R\&D. Bandung : Alfabeta

Suryaningsih, Yeni. 2016. Implementasi Pembelajaran Terpadu Tipe Shared untuk Meningkatkan Kecerdasan Spiritual Siswa. Jurnal Bio Educatio, Vol. 1 No. 1 Hal. 64-71. Tersedia Pada : https://jurnal.unma.ac.id/index.php/BE/article/view/437. (Diakses pada 7 Januari 2018).

Wahyuni, S. 2017. "Keaktifan Dan Hasil Belajar Melalui Model Pembelajaran Kooperatif Tipe Make A Match Berbantuan Media Gambar". E-Journal Mitra Pendidikan, Volume 1, No. 2, (hlm 83-94). Tersedia pada http://e-jurnalmitrapendidikan.com/index.php/ejmp/article/download/61/22. (Diakses pada 7 Januari 2018).

Yusuf, M dan Wulan, A, R. 2015.Penerapan Model Discovery Learning Menggunakan Pembelajaran Tipe Shared dan Webbed untuk Meningkatkan Penguasaan Konsep dan KPS Siswa. Journal EDUSAINS.Vol.1, No.2 Desember 2015. 